\title{
Fifteen per cent solution to keep Britain in synchrotron club
}

London

BRITAIN's reputation as a fickle collaborator on international science projects has been further reinforced after last week's meeting of the European Synchrotron Radiation Facility (ESRF) council in Grenoble, France. Nine of the ten member states were able to give provisional commitment on funding the facility. Embarrassed UK delegates could not say how much money Britain will be able to afford, or indeed if it will remain a partner. Britain has until the end of the year to come up with a subscription fee acceptable to the other members.

Originally, five nations were involved in ESRF's $£ 3$ million foundation study, each member contributing a sum roughly in proportion to its gross national product: France (38 per cent), West Germany (28), Britain (15), Italy (15), Spain (4). Since the foundation phase started in April last year, five more countries have joined the venture, Switzerland and a "Nordic consortium' of Norway, Denmark, Sweden and Finland. The Nordic countries will together contribute 4 per cent, as will Switzerland.

At last week's meeting, the ESRF council formally approved the foundation phase report, which covers an 11-year period, $6 \frac{1}{2} 2$ years for the machine's construction and $4 \frac{1}{2}$ for experimentation, at a cost of $£ 350$ million. The ESRF council wants work to start next year.

The council will meet in November and again in December, when final levels of funding will be agreed. Britain's contribution according to a formula based on gross national product should be of the order of 18 per cent. The other partners consider 15 per cent acceptable, but might not be prepared to tolerate a disproportionately small subscription fee from what is still seen as a wealthy nation. Britain's position depends on the outcome of the government's public spending review in the autumn.

The Science and Engineering Research Council (SERC) is keen to see Britain in ESRF. The present difficulties have arisen principally because SERC failed to entice France to enter a collaborative arrangement on the spallation neutron source, ISIS, at the Rutherford Appleton Laboratory. SERC had hoped that France would agree to take a 20 per cent stake in the facility. Discussions are still proceeding along similar lines with Italy.

Synchrotron users in Britain are lobbying hard for inclusion in ESRF at the level being requested. As with most international collaborative ventures, contracts for building the machine will be awarded to individual countries in proportion to their contribution, and the input and influence of the scientists using the facility will be similarly determined. Such advanjoin the facility once it had been built. Furthermore, ESRF's supporters say, the sums involved are, by comparison with other international projects, relatively small. At 15 per cent, Britain's contribution would be on average between $£ 5$ million and $£ 6$ million annually for the 11-year period, with the 1988 contribution possibly as low as $£ 1.5$ million.

As with Britain's involvement with the European Space Agency (ESA) and the European Organization for Nuclear Research (CERN), discussions on funding are plagued by uncertainty and patience on the Continent is wearing thin.

Meanwhile, a $£ 1$ million upgrading of SERC's own synchrotron source at Daresbury in Cheshire has been completed. The high brightness lattice is a modification of the $2 \mathrm{GeV}$ synchrotron radiation source, increasing its brilliance by an order of magnitude. Inaugurating the new high brightness lattice on September 17, higher education minister Robert Jackson extolled the benefits of international collaboration on scientific projects. The irony of his remarks will not be lost on the beleaguered British officials at CERN, ESA and now ESRF. Simon Hadlington tages would be lost if Britain decided to

\section{Europe's half-hearted research budget}

\section{London}

THE twelve Common Market governments were expected this week finally to approve the five-year Framework programme of research and development. The budget will be far leaner than the $\mathfrak{£} 7,300$ million originally proposed, mainly at Britain's insistence that the programme in its original form was too costly and unfocused. The final figure is expected to be around $£ 3,700$ million, with the possibility of a further $£ 300$ million at the end of the year if community spending in other areas, notably agriculture, is brought under control to the satisfaction of all members.

Among the first casualties of the reduced research budget are more than half the projects selected as eligible for support under the latest phase of the BRITE (Basic Research in Industrial Technologies for Europe) programme. Last week 46 projects were selected for grant-aid worth $£ 31$ million. A total of 471 projects had been submitted for consideration, of which $\mathbf{2 5 0}$ were deemed eligible. A further 66 projects should receive $\mathbf{£} \mathbf{4 5}$ million after ratification of the Framework budget. More projects could have been supported had the original levels of funding been agreed, say officials.

The BRITE programme, launched in 1985 as a four-year project to increase the use of advanced technologies in traditional industry, now supports some 210 projects. Simon Hadlington

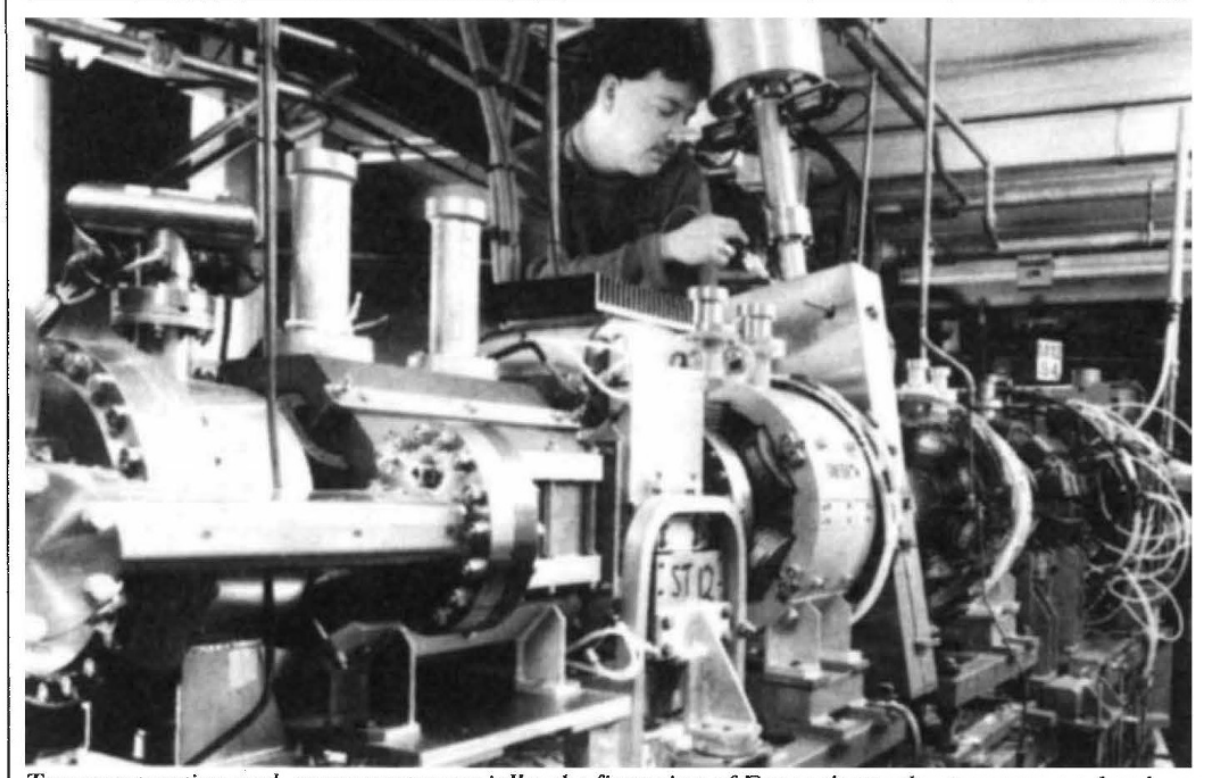

THE construction and, more controversially, the financing of Europe's synchrotron sources has long been an area rife with international horse-trading. At an early phase in the negotiations to build the ESRF at Grenoble, the British partners (SERC) were keen to gain collaborators to share in the costs of the Spallation Neutron Source at Daresbury, near Oxford. French budget cuts last year effectively spelt the end to such hopes (Nature 321, 7; 1987), although now that the Daresbury source is in operation, the facility is open to experimenters from other countries who pay for time on the machine and related services. One of the refinements to the Daresbury synchrotron now upgraded is a smaller more concentrated beam, achieved by adding new focusing magnets (centre of photo above) to every straight section of the storage ring 